\title{
Low VEGF expression in conceptus material and maternal serum AFP and $\beta$-hCG levels as indicators of defective angiogenesis in first-trimester miscarriages
}

\author{
Illk trimester gebelik kayılarında, yetersiz anjiogenez'in göstergesi olarak \\ konseptus materyalinde düsük VEGF ekspresyonu ve maternal serum AFP ve \\ $\beta$-hCG düzeyleri \\ Gülşen Kutluer ${ }^{1}$, Nedim Mahmut Çiçek ${ }^{1}$, Özlem Moraloğlu ${ }^{1}$, Pervin Ertargın ${ }^{1}$, Esma Sankayal ${ }^{1}$ İshak Artar ${ }^{1}$ Özlem Erdem² \\ 'Department of Perinatology and Family Planning, Zekai Tahir Burak Women's Health Resource and Education Hospital, \\ Ankara, Turkey \\ ${ }^{2}$ Department of Pathology, Faculty of Medicine, Gazi University, Ankara, Turkey
}

\section{Abstract}

Objective: The aims of this study were to assess the relationship between early miscarriages and vascular endothelial growth factor (VEGF) expression and to determine the serum levels of first-trimester maternal alpha-fetoprotein (AFP) and human chorionic gonadotropin $(\beta-\mathrm{hCG})$ as markers of angiogenesis and predictors of abortion and intrauterine fetal loss.

Material and Methods: The present study was a prospective, singlecenter, randomized controlled clinical trial. Ninety-five women who were 6-10 weeks pregnant between May and June 2010 were included in the study. The subjects were divided into three groups, i.e., incomplete abortion (IA) $(n=31)$, intrauterine death (IU-D) $(n=32)$ and control (elective pregnancy termination) $(n=32)$. Feto-placental materials were compared based on immune staining for VEGF in the pathology laboratory, and maternal serum samples were tested in the hormone laboratory.

Results: Serum $\beta$-hCG levels in the patient groups were significantly lower than the controls $(\mathrm{p}=0.001)$. The serum AFP level was lower than the controls in the IA group while it was higher than the controls in the IU-D ( $p=0.016)$. Immunohistochemistry showed that the cytotrophoblast, syncytiotrophoblast and endometrial gland epithelium were weakly stained for VEGF in the patient groups (IA and IU-D) in comparison to the control group ( $\mathrm{p}=0.06, \mathrm{p}=0.028, \mathrm{p}=0.006$ ).

Conclusion: Early pregnancy losses are related to insufficient angiogenesis, and maternal serum AFP and $\beta$-hCG can be used as markers of angiogenesis in the first trimester.

(J Turkish-German Gynecol Assoc 2012; 13: 111-7)

Key words: Abortion, implantation, angiogenesis, VEGF, $\beta$-hCG, AFP

Received: 20 October, 2011

Accepted: 18 December, 2011
Özet

Amaç: Erken gebelik kayıplarının vasküler endotelial growth faktör (VEGF) ekspresyonu ile ilişkisini değerlendirmek ve anjiogenez markırı olarak ilk trimester maternal serum alfa-fetoprotein (AFP) ve human chorionic gonadotropin ( $\beta$-hCG) düzeylerinin abortusu ve intrauterin fetal ölümü öngörmedeki yerini tespit edebilmektir.

Gereç ve Yöntemler: Çalışmamıza, Mayıs 2010 ve Temmuz 2010 tarihleri arasında hastanemize başvuran, 6-10. gebelik haftalarındaki toplam 95 hasta dahil edildi. Hastalar inkomplet abortus $(n=31)$, intrauterin ex $(n=32)$ ve kontrol $(n=32)$ olarak 3 grup halinde incelendi. Fetoplasental materyaller patoloji laboratuarında VEGF ile immün boyanma özellikleri açısından karşılaştırıldı. Maternal serum örnekleri hormon laboratuvarında çalışıldı.

Bulgular: Serum $\beta$-hCG değeri hasta gruplarında, kontrole göre anlamlı olarak düşük $(\mathrm{p}=0.001)$ ve serum AFP değeri de İA grubunda kontrole göre düşük, IUEX grubunda ise yüksek saptandı $(\mathrm{p}=0.016)$. İmmünhistokimya ile, sitotrofoblast, sinsityotrofoblast ve endometrial gland epitel hücrelerinde hasta gruplarında (İA VE İUEX) kontrol grubuna kıyasla VEGF için daha zayıf boyanma olduğu görüldü $(\mathrm{p}=0.06$, $\mathrm{p}=0.028, \mathrm{p}=0.006$ ).

Sonuçlar: Erken gebelik kayıları, yetersiz anjiogenezle ilişkilidir ve VEGF ile ilisskili olarak, ilk trimesterde maternal serum AFP ve $\beta$-hCG'nin anjiogenez markırı olarak kullanımı olasıdır.

(J Turkish-German Gynecol Assoc 2012; 13: 111-7)

Anahtar kelimeler: Abortus, implantasyon, anjiogenez, VEGF, $\beta$-hCG, AFP

Geliş Tarihi: 20 Ekim $2011 \quad$ Kabul Tarihi: 18 Aralık 2011

cular endothelial growth factor (VEGF) plays the key role (1). VEGF exerts angiogenic effects via two receptors; VEGFR-1/ Flt-1(fms-like-tyrosine kinase) and VEGFR-2/flk-1 (fetal liver kinase)/KDR (kinase domain region) (2). The role of VEGF was first described in a gene deletion study by Carmaliet et al., (3) who reported in 1995 that embryonic mice which 
were unable to produce VEGF or were defective at the level of the VEGF receptor did not develop normal vascular structures and were aborted. Evans and coworkers showed that the concentration of VEGF in the maternal serum was elevated in early first trimester pregnancies (4). In an immunohistochemical study by Kaloglu et al., (5) the role of VEGF in placental angiogenesis was established. It has been reported that VEGF not only stimulates and regulates angiogenesis but also guides implantation by promoting the growth of the cytotrophoblasts and differentiation via these receptors (6). In addition to the well-defined angiogenic factors such as VEGF, recent studies have revealed that growth factors and hormones related to gestation, especially human chorionic gonadotropin (hCG), alpha-fetoprotein (AFP) and insulin-like growth factor II (IGF II), play important roles in the vascular development of the feto-placental unit (7-10). Laitinen et al. (11) showed the direct effect of hCG on VEGF expression via the hCG/LH receptor. Herr et al. (8) argued that hCG stimulates the proliferation of human placental micro vascular endothelial cells in a dose-dependent fashion and that it is critical for a successful pregnancy due to its role in immune tolerance. AFP is a protein synthesized in the yolk sac and liver of the fetus and plays an important role as a proangiogenic factor in VEGF-dependent angiogenesis, especially in the endothelial cells of the feto-maternal unit (9). There are a few papers in the literature on maternal serum AFP (MS-AFP) levels in the first trimester $(9,10,12,13)$. Previous studies have shown that the levels of endocrinological factors, such as hCG, progesterone $(14,15)$, pregnancy associated plasma protein-A (PAPP-A) and inhibin A (13) levels, are decreased in the first trimester in patients with symptoms of threatened miscarriage (TM) who subsequently had a complete miscarriage, compared to those with a normal obstetric outcome.

The aim of the present study was to detect and compare VEGF immunoreactivity among feto-maternal materials obtained as a result of spontaneous incomplete abortion (IA), intrauterine death (IU-D) and elective termination of pregnancy (control) and to determine the values of first-trimester maternal serum levels of AFP and $\beta$ - hCG as markers of angiogenesis and predictors of abortion and intrauterine fetal losses.

\section{Material and Method}

The present study was a prospective, single-center, randomized controlled clinical trial assessing the VEGF immunoreactivity and the values of first-trimester maternal serum levels of AFP and $\beta$-hCG among feto-maternal materials obtained as a result of spontaneous incomplete abortion (IA), intrauterine death (IU-D) and elective termination of pregnancy (control). Ethical approval was obtained from the local research ethics committee prior to the study, and written informed consent were obtained from all patients. This study was conducted in accordance with the basic principles of the Helsinki Declaration.

\section{Patient selection:}

A group of 124 patients ranging from 6-10 gestational weeks in their pregnancies admitted to the Family Planning Unit of Zekai Tahir Burak Women Training and Research Hospital, Ankara, Turkey, between May 2010 and July 2010 were eligible for inclu- sion in this trial. Before the subjects were enrolled in the study, age, gravida, parity, abortus weight, height, body mass index (kg/height ${ }^{2}$ ) (BMI), the presence of a systemic disease (such as diabetes, hypertension), smoking, alcohol consumption, caffeine consumption, medications, blood group incompatibility and first day of the last menstrual period were recorded. Subjects with a systemic disease or an etiological risk factor for recurrent abortion, subjects who conceived by assisted reproductive techniques or had Rh incompatibility and smokers were not included in the study $(n=12)$. All subjects underwent pelvic examination in the dorsolithotomy position. Conditions that might cause vaginal bleeding, such as cervical carcinoma, ulcer, polyp, erosion, vaginal laceration, and vaginitis, were ruled out $(n=11)$. Patients with trophoblastic disease, ectopic pregnancy and multiple pregnancies, identified by pelvic and ultrasound examination, were also excluded from the study $(n=6)$. Therefore, the remaining 95 patients were included in the study.

\section{Study Design:}

Patients were divided into three groups. The IA group comprised 31 patients who had a live fetus within the uterine cavity but who had experienced spontaneous incomplete abortion within 12 hours before admittance to the hospital. (Gestational material for immunohistochemical examination was obtained only from 16 cases). Thirty-two patients were allocated into the IU-D group when the crown-rump length (CRL) was over 5 mm but a fetal heart beat was absent, based on trans-vaginal ultrasound (TVU) examination. The control group comprised 32 normal subjects who underwent elective termination of their pregnancies.

All pregnancies were terminated by vacuum aspiration, and two venous blood samples of $3 \mathrm{cc}$ were taken from each patient's antecubital vein just before the procedure. Blood samples were centrifuged at $4500 \mathrm{rpm}$ for 15 minutes to separate the serum. $\beta$-hCG and AFP were measured using these sera.

Diagnoses of the patients in the IA group were made by gynecological examination or observation with TVU of gestational material within the cervical canal and serial $\beta$-hCG measurements and were confirmed histopathologically after curettage. The IU-D group included patients with fetuses with a CRL $\geq 5$ mm but without a fetal heart beat on TVU exam. Subjects in the control group were evaluated by TVU to determine the location of the fetus, heart beat and biometric size (CRL).

$\beta$-hCG measurements: Sera were analyzed on the same day as sample collection using the $\beta$ - hCG kit by the Heterogenous Enzyme Immunoassay method, and the results were expressed in $\mathrm{mIU} / \mathrm{ml}$. All samples were assayed in duplicate, and the intraand inter-assay variations based on undiluted $170 \mathrm{mIU} / \mathrm{ml}$ BioRad hCG control were $3.2 \%$ and $6.7 \%$, respectively.

AFP measurements: Sera were analyzed on the same day as sample collections in the hormone laboratory for AFP by Enzyme-Linked Immunosorbent Assay (Genentech, Inc., San Francisco, California), and AFP levels were quantified as IU/ml. The intra- and inter-assay coefficients of variation were calculated as $2.8 \%$ and $3.8 \%$, respectively.

Histopathological and Immunohistochemical Method: All feto-placental curettage material was sent to the Pathology 
Laboratory. Specimens were fixed in formalin and embedded in paraffin after routine histological processing, and tissue blocks were obtained. Tissue blocks were then sectioned, deparaffinized and rinsed under running tap water. Sections were incubated in $3 \%$ hydrogen peroxide for 10 minutes, rinsed under distilled water and pretreated at a high temperature in a microwave oven in Tris-EDTA buffer ( $\mathrm{pH}$ 9) for 20 minutes. After waiting at room temperature for 20 minutes, sections were washed in PBS (phosphate buffered saline, $\mathrm{pH}$ 7.6) for 5 minutes. After application of the protein block for 10 minutes, sections were incubated with the primary antibody at room temperature for one hour (VEGFAb-1 Rabbit Polyclonal Antibody, Thermo Scientific RB222) and then washed with PBS for 5 minutes. The sections were incubated for $20 \mathrm{~min}$ with a biotinylated secondary antibody, washed with PBS for 5 minutes, incubated with streptavidin/peroxidase complex for 20 minutes, washed with PBS for 5 minutes and incubated with AEC chromogen for 5 minutes. Slides were washed under tap water, counterstained with Mayer's Hematoxylin for 30 seconds, washed with distilled water and covered with a water-based cover material.

To reduce intra- and inter-observer variability, materials were numbered and examined by a single pathologist who was blind to the group to which the specimen belonged. Tissues that were immunostained and examined under light microscope included trophoblasts around the chorionic villi (syncytiotrophoblasts, cytotrophoblast), Hofbauer cells (fetal tissue macrophages) within the chorionic villi stroma, the vascular endothelium of the chorionic villi on the fetal side as well as the decidual stromal cells, the decidual vascular endothelium and the endometrial gland epithelium on the maternal side.

The tissue sections were compared based on immunostaining for VEGF. We observed that the VEGF antibody stained the cytoplasm and cell membrane, but not the nucleus. In other words, sections were evaluated based on positive staining or membranous staining of the cells. Sections were graded on a 4-point scale which is commonly used in immunohistochemical studies. Sections were scored as; 0: No staining, 1+: focal, weak staining, $2++$ : diffuse, weak staining, $3+++$ : diffuse, strong staining.

Outcome variable and statistical analysis:

To differentiate between the control, IA and IU-D groups using the AFP values, the power was calculated as 0.97 at \pm 4 units of deviation from the mean, and alpha was taken as 0.05 (Calculated by NCSS-PASS software package).

SPSS (Statistical Package for Social Sciences) for Windows 15.0 was used for statistical analyses. In addition to descriptive statistics (mean, standard deviation, median), one-way ANOVA, Kruskal-Wallis $\mathrm{H}$, and Mann-Whitney $\mathrm{U}$ tests were used for comparison of quantifiable data. Differences between groups were considered significant when $\mathrm{p}<0.05$ and $\mathrm{p}<0.01$ at $95 \%$ and $99 \%$ confidence intervals.

\section{Results}

Table 1 shows the demographic and descriptive data of the patients, including age, gravida, parity, live births, abortus, dilation and curettage (D\&C), and body mass index (BMI). There were no significant differences in age and BMI between groups (Table 1). The mean gestational ages of the groups according to last menstrual period and ultrasound were $7.6 \pm 1.3$ and $6.5 \pm 0.81$, respectively.

Significant differences in the mean $\beta$-hCG levels of the subjects were found between groups; the mean $\beta$-hCG level in the IA group was lower $(p=0.001)$ (Table 2$)$. There was also a significant difference in mean AFP levels between groups. Compared to the controls, the mean AFP was lower in the IA group, but higher in the IU-D group $(\mathrm{p}=0.016)$ (Table 2$)$.

Comparison of tissue sections in terms of VEGF staining revealed that the cytotrophoblasts and syncytiotrophoblasts of the placental villi and endometrial gland cells stained significantly weaker in the patient groups (IA and IU-D) in comparison to the controls (Table 3, Figures 1-3). Hofbauer cells in the control group stained similarly to those in the IA and IU-D groups, and there were no statistically significant differences in staining intensity (Table 3). Vascular endothelial cells of the placental villi stained weakly in the control group as opposed to the IA and IU-D groups, and the differences between the patient groups and the controls in terms of VEGF staining intensity were significant (Table 3, Figures 4 and 5). Decidual stromal cells stained comparably in all groups with no statistically significant differences among them (Table 3, Figure 6). Decidual vascular endothelial cells presented weaker staining in the control and IA groups than the IU-D group, but the differences did not reach the level of significance (Table 3).

Table 1. Comparison of the patient demographics and descriptive data

\begin{tabular}{|c|c|c|c|c|}
\hline & $\begin{array}{c}\text { Control } \\
(\text { Mean } \pm \text { SD) } \\
\mathbf{n}=32\end{array}$ & $\begin{array}{c}\text { IA } \\
(\text { Mean } \pm \text { SD) } * * \\
\mathbf{n}=\mathbf{3 1}\end{array}$ & $\begin{array}{c}\text { IU-D } \\
(\text { Mean } \pm \text { SD)** } \\
\mathbf{n}=32\end{array}$ & p value* \\
\hline Parity & $2.4063 \pm 1.7387$ & $1.6452 \pm 1.6030$ & $0.9688 \pm 1.0920$ & $0.001 *$ \\
\hline Live birth & $2.2500 \pm 1.1639$ & $1.5484 \pm 1.5671$ & $0.9375 \pm 1.0453$ & $0.001 *$ \\
\hline Abortus & $0.2813 \pm 0.6831$ & $0.2258 \pm 0.6688$ & $0.3125 \pm 0.7803$ & 0.798 \\
\hline Age (years) & $31.25 \pm 5.968$ & $30.90 \pm 6.655$ & $30.88 \pm 7.241$ & 0.969 \\
\hline BMI (kg/height $\left.{ }^{2}\right)$ & $25.6594 \pm 4.8746$ & $24.0290 \pm 3.6455$ & $24.2188 \pm 5.1477$ & 0.310 \\
\hline
\end{tabular}


Table 2. The means of serum $\beta$-hCG and AFP values in the groups

\begin{tabular}{|l|c|c|c|c|}
\hline & $\begin{array}{c}\text { Control } \\
(\text { Mean } \pm \text { SD) } \\
\mathbf{n}=\mathbf{3 2}\end{array}$ & $\begin{array}{c}\text { IA } \\
(\text { Mean } \pm \text { SD) } \\
\mathbf{n}=\mathbf{3 1}\end{array}$ & $\begin{array}{c}\text { IU-D } \\
\left(\begin{array}{c}\text { Mean } \pm \text { SD)* } \\
\mathbf{n = 3 2}\end{array}\right.\end{array}$ & p value \\
\hline$\beta-\mathrm{hCG}(\mathrm{mIU} / \mathrm{ml})$ & $71479 \pm 6453.57$ & $9491.00 \pm 3118.871$ & $34492.74 \pm 7799.917$ & 0.001 \\
\hline AFP $(\mathrm{IU} / \mathrm{ml})$ & $5.2594 \pm 2.6591$ & $3.4645 \pm 2.3656$ & $7.8000 \pm 2.0128$ & 0.016 \\
\hline *Data are expressed as the mean \pm standard deviation (SD)
\end{tabular}

Table 3. The median and range of the intensity of VEGF staining of the groups

\begin{tabular}{|c|c|c|c|c|}
\hline & $\begin{array}{l}\text { CONTROL } \\
\text { (Median) } \\
\text { (Range) }\end{array}$ & $\begin{array}{c}\text { IA } \\
\text { (Median) } \\
\text { (Range) } \\
\end{array}$ & $\begin{array}{c}\text { IU-D } \\
\text { (Median) } \\
\text { (Range) }\end{array}$ & $\mathbf{p}$ \\
\hline CYTOTROPHOBLAST & $\begin{array}{c}3 \\
2.15-2.66\end{array}$ & $\begin{array}{c}2 \\
1.40-2.35\end{array}$ & $\begin{array}{c}2 \\
1.67-2.33\end{array}$ & 0.066 \\
\hline SYNCYTIOTROPHOBLAST & $\begin{array}{c}3 \\
2.15-2.66\end{array}$ & $\begin{array}{c}2 \\
1.40-2.35\end{array}$ & $\begin{array}{c}2 \\
1.57-2.22\end{array}$ & $0.028 *$ \\
\hline HOFBAUER CELLS & $\begin{array}{c}1 \\
1.01-1.68\end{array}$ & $\begin{array}{c}1 \\
0.44-1.43\end{array}$ & $\begin{array}{c}1 \\
0.55-1.31\end{array}$ & 0.158 \\
\hline $\begin{array}{l}\text { PLACENTAL VASCULAR } \\
\text { ENDOTHELIAL CELLS }\end{array}$ & $\begin{array}{c}0.00 \\
0.02-0.29\end{array}$ & $\begin{array}{c}0.50 \\
0.26-1.11 \\
\end{array}$ & $\begin{array}{c}0.50 \\
0.52-1.34 \\
\end{array}$ & $0.003 * *$ \\
\hline STROMAL CELLS & $\begin{array}{c}2 \\
1.87-2.45\end{array}$ & $\begin{array}{c}2 \\
1.48-2.39\end{array}$ & $\begin{array}{c}2 \\
1.58-2.42\end{array}$ & 0.736 \\
\hline $\begin{array}{l}\text { DECIDUAL VASCULAR } \\
\text { ENDOTHELIAL CELLS }\end{array}$ & $\begin{array}{c}0.50 \\
0.38-1.00\end{array}$ & $\begin{array}{c}0.50 \\
0.26-1.11\end{array}$ & $\begin{array}{c}1 \\
0.74-1.55\end{array}$ & 0.165 \\
\hline $\begin{array}{l}\text { ENDOMETRIAL GLAND } \\
\text { CELLS }\end{array}$ & $\begin{array}{c}1 \\
1.13-1.81\end{array}$ & $\begin{array}{c}0.50 \\
0.33-1.42\end{array}$ & $\begin{array}{c}0 \\
0.33-1.03\end{array}$ & $0.006^{* *}$ \\
\hline
\end{tabular}

\section{Discussion}

Aiming to clarify the etiopathogenesis of first-trimester miscarriages, we examined VEGF staining in tissue sections prepared from the feto-placental materials collected from our patients and measured $\beta$-hCG and AFP levels in maternal serum. We constructed two patient groups, namely a spontaneous incomplete abortion group and an intrauterine death group, and we compared their results with those of the controls. Few studies exist in the literature that measured MS-AFP in the first trimester. It is usually investigated during the diagnoses of fetal chromosomal anomalies and neural tube defects in the later stages of pregnancy $(13,16)$. Previous studies have reported a strong association between low MS-AFP $(<0.05 \mathrm{MoM})$ and gestational complications, such as fetal death, spontaneous abortion, anembryonic pregnancy, preterm labor and macrosomia (16-21). In addition to fetal chromosomal anomalies, high MS-AFP (AFP $>2.5$ MoM) has been shown to be related to placental pathology, multiple pregnancy and fetal death (13). In agreement with findings reported in the literature, the mean MS-AFP in the IA group was lower $(\mathrm{AFP}=3.4645 \mathrm{IU} / \mathrm{ml})$, while that in the IU-D group was significantly higher $(\mathrm{AFP}=7.8000 \mathrm{IU} / \mathrm{ml})(\mathrm{p}=0.016)$. An immunohistochemical study on endothelial cell culture from the human feto-maternal units by Liang et al. showed that

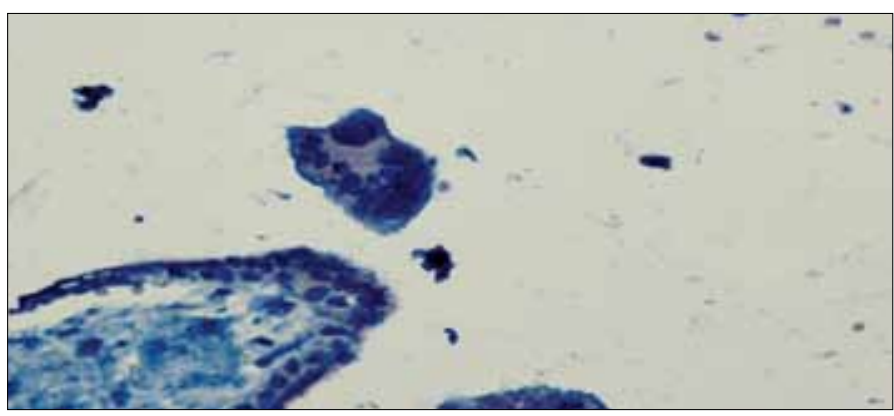

Figure 1. Cytotrophoblasts and syncytiotrophoblasts that show focal weak VEGF staining (1) in the IA group. 400X

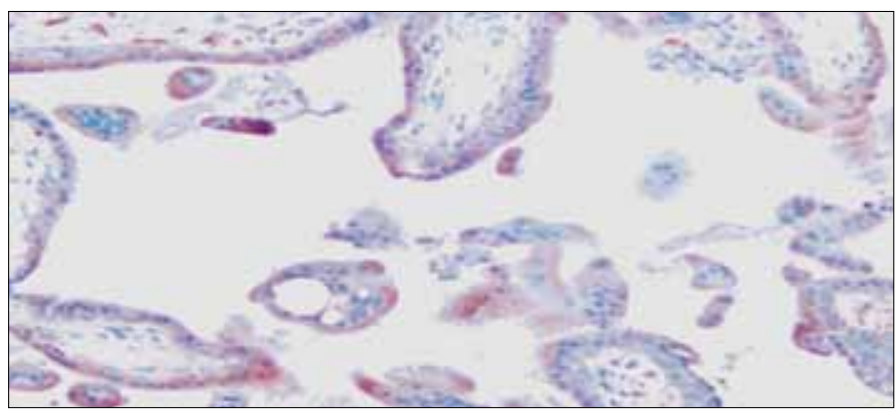

Figure 2. Cytotrophoblasts and syncytiotrophoblasts that show diffuse weak VEGF staining in the IU-D group. 400X 


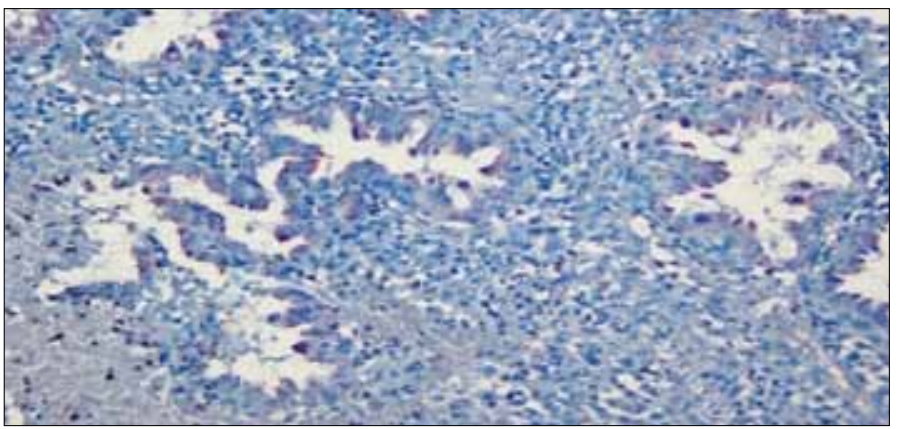

Figure 3. Endometrial gland cells that show focal weak VEGF staining in the IA group. 400X

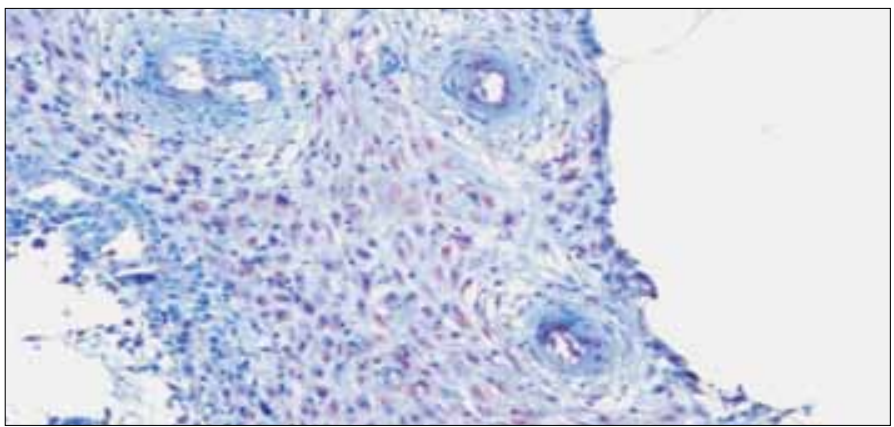

Figure 4. Decidual vascular endothelial cells that show diffuse weak VEGF staining (2) in the IA group. 400X

stimulation of VEGF-dependent proliferation depended on the dose of AFP and that the optimal dose should be at least 100 $\mathrm{ng} / \mathrm{ml}$ (9). Sande et al. (22) argued that the best indicator of a threatened miscarriage is the $\beta$-hCG level, and that AFP and human chorionic somatomammotropin (HCS) levels were equal indicators but not as reliable as $\beta$-hCG. The authors also argued that the AFP level was more diagnostic than HCS because both high and low levels of AFP suggest that a pregnancy could progress unfavorably. In the present study, the mean serum $\beta$-hCG levels in the patient groups were significantly lower than in the control group, and the lowest level was measured in the IA group $(\beta-\mathrm{hCG}=9491 \mathrm{MIU} / \mathrm{ml})$ $(p=0.001)$. Johns et al. (23) reported that serum $\beta$-hCG levels in the first trimester were lower in pregnancies that ended in miscarriage than in those that reached term. Zygmunt et al. (24) highlighted the importance of angiogenesis in early pregnancy, showing that hCG not only had a trophoblast invasion stimulating effect but also was an important angiogenic factor for the feto-maternal unit (10). Numerous studies have shown that defective vascular development underlies many early pregnancy losses and incidents of intrauterine embryonic death $(7,22,25)$. hCG stimulates VEGF via the LH receptor, and together they play roles in peritrophoblastic angiogenesis (25). Moreover, previous studies have demonstrated a positive correlation between serum hCG and serum VEGF levels during the early embryonic period, and this is important for a successful pregnancy $(25,26)$. In a review by Ferrara, the author reported that VEGF was the key regulator in normal and pathological angiogenesis (27). The authors also noted that loss of a single VEGF allele could result in early embryonic

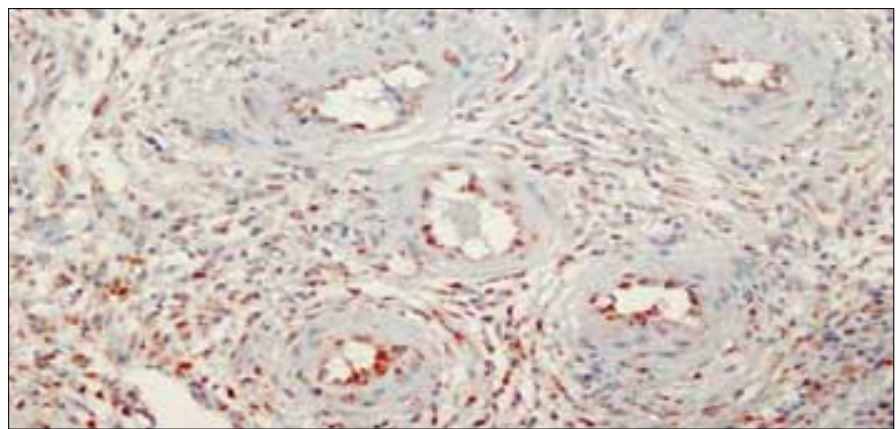

Figure 5. Decidual vascular endothelial cells that show diffuse weak VEGF staining (2) in the IU-D group. 400X

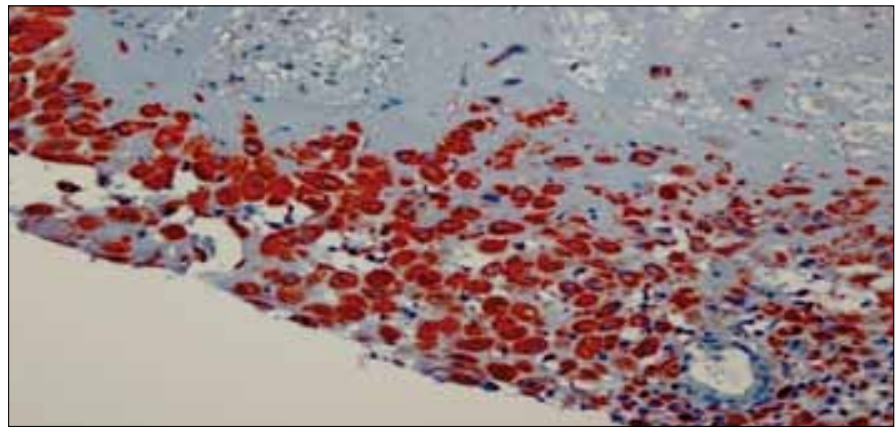

Figure 6. Decidual stromal cells that show diffuse strong VEGF staining in the control group. $400 \mathrm{X}$

death due to insufficient vascularization (27). In this study, we noted that changes in VEGF levels in the 6th-10th gestational weeks, and the conceptus material was significant enough to show defective angiogenesis, which was consistent with concurrent serum hCG and AFP levels. Compared to the control group, weaker staining of cytotrophoblasts, syncytiotrophoblasts and endometrial gland epithelial cells was noteworthy in the both patient groups (IA and IU-D). At this stage, the lower level of $\beta$-hCG, which is released in particular from the syncytiotrophoblasts, in the patient groups was attributed to defective angiogenesis. Studies by Demir et al. $(28,29)$ demonstrated that, in a normal pregnancy, the villous cytotrophoblastic cells, followed by Hofbauer cells of the villus stroma, strongly express VEGF, although the villous endothelium lacked immunostaining for VEGF (10). In this study, we found that Hofbauer cells and decidual stromal cells were stained comparably in all groups. They suggested that vascular endothelium revealed a clear decrease in VEGF staining intensity in normal human placental villi sections from days 22 to 48 post conception of gestation (28). So, this normal developmental physiology can explain why vascular endothelial cells of the placental villi stained weakly in the control group in our study. Kayisli et al. (30) reported that, in normal early pregnancy, vascular endothelial cells of the placental villi revealed weaker VEGF immunoreactivity than trophoblasts in all pregnancy weeks. They evaluated placental vasculogenesis in their study and they evaluated angiogenic proteins (Tie-1 and Tie-2) in the different stages of vasculogenesis related to cell type, villous maturation and pregnancy age during very early placental development (30). They also found that vascular endothelium 
displayed a gradual decrease from strong to weak for Tie-2 immunoreactivity. Demir et al. (29) sugessted that expression of VEGF and its receptors VEFR-1 and VEGFR-2, and angiopoietin receptors Tie-1 and Tie-2 in parallel to vascular maturation in human placental villi during very early stages of placental development. Vuorela et al. (31) described diminished placental trophoblastic VEGF immunoreactivity, reduced placental trophoblastic Tie-1 and Tie-2 expression and weaker VEGFR-1, VEGFR-2,Tie-1 and Tie-2 expression in decidual endometrium of spontaneous abortions and these results are similar of our results in which we found that the cytotrophoblasts and syncytiotrophoblasts of the placental villi and endometrial gland cells stained significantly more weakly for VEGF in the patient groups (IA and IU-D) in comparison to the controls. And also they found weak immunostaining for VEGF in vascular endothelium of the placental villi of the healthy controls similar with our study. In their study, decidual stromal cells showed faint VEGF and medium VEGFR-3 immunoreactivity in all study groups (31). They found negative reactions for VEGF and VEGFR-1 and VEGFR-3 of decidual vascular endothelium in all study groups, similar of our results. They reported that recurrent miscarriage might be associated with alterations in the expression of VEGF, VEGF receptors-1,-2,-3 and Tie-1 and Tie-2 receptors (31). Sugino et al. (32) reported that decidual stromal cells stained strongly for VEGF and its receptors between 6 and 8 weeks of gestation. An immunohistochemical study by Kaufmann (33) demonstrated that VEGF, especially in the early stages of pregnancy, is expressed by villous trophoblasts and Hofbauer cells, and the authors considered this to be the initial stage of normal angiogenesis. In the same study, the authors showed that, for both VEGF-A and its receptor VEGFR-2 (KDR/ flk-1), this stage corresponded to the transition from secondary villi to tertiary villi, which also occurs at 21-32 days post conception (33). The soluble form of VEGF (VEGRF-1) and placental growth factor (PIGF) are expressed during later stages (branching angiogenesis phase), i.e., between 32 days and 25 weeks of gestation (28-33). Therefore, the levels of serum (soluble) VEGF would not be suitable to predict early pregnancy loss. Hence, we used serum AFP and $\beta$-hCG instead of serum VEGF as markers of early angiogenesis. There are no reliable assays available to measure 'total' VEGF in the circulation, and circulating levels of VEGF are almost undetectable in early pregnancy (34). Angiogenic growth factors (VEGF-A and PIGF) have been investigated extensively in normal and abnormal placental vascular development (35-37). Romero et al. (38) reported associations between PIGF and soluble VEGF and late gestational complications such as pre-eclampsia. Conversely, Muttukrishna et al. (39) demonstrated that soluble vascular endothelial growth factor receptor-1(sFlt-1) and PlGF could be new sensitive predictors of a subsequent miscarriage in patients with TM in the first trimester. They suggested that, with its short half-life in the maternal circulation, sFlt-1 could be a more sensitive marker than other molecules such as hCG, which have a longer half-life (39). They concluded that, whereas the lowering of P1GF may be related to a decreased syncytiotrophoblast synthesis, lower levels of sFlt-1 may be compensatory as the placenta may be producing more VEGF and less sFlt-1, which is bound to VEGF.
On the other hand, both VEGF and the receptor production may be lower in patients who subsequently have a miscarriage, thus reflecting lower levels of sFlt-1 in maternal circulation in these cases (39).

\section{Conclusion}

At present, there is no reliable marker to predict the clinical outcome of women presenting with TM in the first trimester of pregnancy, although several potential markers have been studied $(14,15)$.

Our results indicate that early pregnancy loss is associated with low VEGF expression, and this association possibly originates from the villous cytotrophoblasts, syncytiotrophoblasts and endometrial gland epithelium. In line with these results, it is possible to use maternal serum $\beta$-hCG together with MS-AFP as markers of defective angiogenesis in the first trimester to predict early pregnancy losses. Randomized studies with larger sample size are needed to confirm this finding. To date, studies are underway to accomplish therapeutic angiogenesis with VEGF and VEGF gene transfer and to prevent pathological angiogenesis with anti-VEGF antibodies (40-44).

Acknowledgements: We thank the Elsevier Language Editing Service for the English edition of the manuscript.

\section{Conflict of interest}

No conflict of interest was declared by the authors.

\section{References}

1. Ribatti D. The crucial role of vascular permeability factor/vascular endothelial growth factor in angiogenesis: a historical review. $\mathrm{Br} \mathrm{J}$ Haematol 2005; 128: 303-9. [CrossRef]

2. Cunningham SA, Tran TM, Arrate MP, Brock TA. Characterization of vascular endothelial cell growth factor interactions with the kinase insert domain-containing receptor tyrosine kinase. A real time kinetic study. J Biol Chem1999; 274: 18421-7. [CrossRef]

3. Carmeliet P, Ferreira V, Breier G, Pollefeyt S, Kieckens L, Gertsenstein $\mathrm{M}$, et al. Abnormal blood vessel development and lethality in embryos lacking a single VEGF allele. Nature 4 1996; 380: 435-9.

4. Evans PW, Wheeler T, Anthony F, Osmond C. Maternal serum vascular endothelial growth factor during early pregnancy. Clin Sci1997; 92: 567-71.

5. Kaloğlu C, Bulut HE. Vascular endothelial growth factor production by rat granulated metrial gland cells and their morphological features in normal and pathological conditions. Reprod Fertil Dev 2007; 19: 341-50. [CrossRef]

6. Fasouliotis SJ, Spandorfer SD, Witkin SS, Liu HC, Roberts JE, Rosenwaks Z. Maternal serum vascular endothelial growth factor levels in early ectopic and intrauterine pregnancies after in vitro fertilization treatment. Fertil Steril 2004; 82: 309-13. [CrossRef]

7. Tsampalas M, Gridelet V, Berndt S, Foidart JM, Geenen V, Perrier d'Hauterive S. Human chorionic gonadotropin: a hormone with immunological and angiogenic properties. J Reprod Immunol 2010; 85: 93-8. [CrossRef]

8. Herr F, Baal N, Reisinger K, Lorenz A, McKinnon T, Preissner KT, et al. HCG in the regulation of placental angiogenesis. Results of an in vitro study. Placenta 2007; 21: 85-93. [CrossRef]

9. Liang OD, Korff $\mathrm{T}$, Eckhardt $\mathrm{J}$, Rifaat $\mathrm{J}$, Baal $\mathrm{N}$, Herr $\mathrm{F}$, et al. Oncodevelopmental $\alpha$ Fetoprotein Acts as a Selective 
Proangiogenic Factor on Endothelial Cell from the Fetomaternal Unit. The Journal of Clinical Endocrinology \& Metabolism 2004; 89(3): 1415-22. [CrossRef]

10. Zygmunt M, Herr F, Münstedt K, Lang U, Liang OD. Angiogenesis and vasculogenesis in pregnancy. Eur J Obstet Gynecol Reprod Biol 2003; 110: 10-8. [CrossRef]

11. Laitinen M, Ristimaki A, Honkasalo M, Narko K, Paavonen K, Ritvos O. Differential hormonal regulation of vascular endothelial growth factors VEGF, VEGF-B, and VEGF-C messenger ribonucleic acid levels in cultured human granulosa-luteal cells. Endocrinology1997; 138: 4748-56. [CrossRef]

12. Johns J, Hyett J, Jauniaux E. Obstetric outcome after threatened miscarriage with and without a hematoma on ultrasound. Obstet Gynecol 2003; 102: 483-7. [CrossRef]

13. Smith GC, Shan I, Crossley JA, Atiken DA, Pell JP, Nelson SM, et al. Pregnancy-associated plasma protein A and alpha-fetoprotein and prediction of adverse perinatal outcome. Obstet Gynecol Jan 2006; 107: 161-6. [CrossRef]

14. Johns J, Jauniaux E. Threatened miscarriage as a predictor of obstetric outcome. Obstet Gynecol 2006; 107: 845-50. [CrossRef]

15. Duan L, Yan D, Zeng W, Yang X, Wei Q. Predictive power progesterone combined with beta human chorionic gonadotropin measurements in the outcome of threatened miscarriage. Arch Gynecol Obstet 2011; 283: 431-5. [CrossRef]

16. Gagnon A, Wilson RD, Audibert F, Allen VM, Blight C, Brock JA, et al. Obstetrical complications associated with abnormal maternal serum markers analytes. J Obstet Gynaecol Can 2008; 30: 918-49.

17. Doran TA, Valentine GH, Wong PY, Wielgosz G, Benzie RJ, Soltan $\mathrm{HC}$, et al. Maternal serum -fetoprotein screening: report of a Canadian pilot project. CMAJ 1987; 137; 285-93.

18. Krause TG, Christens $P$, Wohlfahrt J, Lei U, Westergaard T, Norgaard-Pedersen B, et al. Second-trimester maternal serum alpha-fetoprotein and risk of adverse pregnancy outcome. Obstet Gynecol 2001; 97: 277-82. [CrossRef]

19. Burton BK. Outcome of pregnancy in patients with unexplained elevated or low levels of maternal serum alpha-fetoprotein. Obstet Gynecol 1988; 72: 709-13.

20. Baschat AA, Harman CR, Farid G, Chodirker BN, Evans JA. Very low second-trimester maternal serum alpha-fetoprotein: Association with high birth weight. Obstet Gynecol 2002; 99: 531-6. [CrossRef]

21. Kiran TS, Bethel J, Bhal PS. Correlation of abnormal second trimester maternal serum alpha-fetoprotein (MSAFP) levels and adverse pregnancy outcome. J Obstet Gynecol 2005; 25: 253-6.

22. Sande HA, Fagerhol M, Molnar O, Foss OP, Torjesen P. Alphafetoprotein: a marker for threatened abortion. Int J Gynaecol Obstet 1979; 16: 293-5. [CrossRef]

23. Johns J, Muttukrishna S, Lygnos M, Groome N, Jauniaux E. Maternal serum hormone concentrations for prediction of adverse outcome in threatened miscarriage. Reprod Biomed Online 2007; 15: 413-21. [CrossRef]

24. Zygmunt M, Herr F, Keller-Schoenwetter S, Munstedt K, Rao CV, Lang $\mathrm{U}$, et al. Characterization of human chorionic gonadotropin as a novel angiogenic factor. J Clin Endocrinol Metab 2002; 87: 5290-6. [CrossRef]

25. Berndt S, Perrier d'Hauterive S, Blacher S, Péqueux C, Lorquet S, Munaut $\mathrm{C}$, et al. Angiogenic activity of human chorionic gonadotropin through $\mathrm{LH}$ receptor activation on endothelial and epithelial cells of the endometrium. FASEB J 2006; 20: 2630-2. [CrossRef]

26. Evans PW, Wheeler T, Anthony FW, Osmond C. A longitudinal study of maternal serum vascular endothelial growth factor in early pregnancy. Human Reprod 1998; 13: 1057-62. [CrossRef]

27. Ferrara N. Role of vascular endothelial growth factor in the regulation of angiogenesis. Kidney Int 1999; 56: 794-814. [CrossRef]

28. Demir R, Kayisli UA, Seval Y, Celik-Ozenci C, Korgun ET, DemirWeusten AY, et al. Sequential expression of VEGF and its receptors in human placental villi during very early pregnancy: differences between placental vasculogenesis and angiogenesis. Placenta 2004; 25: 560-72. [CrossRef]

29. Demir R, Kayisli UA, Cayli S, Huppertz B. Sequential steps during vasculogenesis and angiogenesis in the very early human placenta. Placenta 2006; 27: 535-9. [CrossRef]

30. Kayisli UA, Cayli S, Seval Y, Tertemiz F, Huppertz B, Demir R. Spatial and Temporal Distribution of Tie-1 and Tie-2 During very early development of the human placenta.Placenta 2006; 27: 648-59. [CrossRef]

31. Vuorela P, Carpen O, Tulppala M, Halmesmaki E. VEGF, its receptors and the tie receptors in recurrent miscarriage. Mol Hum Reprod 2000; 6: 276-82. [CrossRef]

32. Sugino N, Kashida S, Karube-Harada A, Takiguchi S, Kato H. Expression of vascular endothelial growth factor (VEGF) and its receptors in human endometrium throughout the menstrual cycle and in early pregnancy. Reproduction 2002; 123: 379-87. [CrossRef]

33. Kaufmann P, Mayhew TM, Charnock-Jones DS.Aspects of human fetoplacental vasculogenesis and angiogenesis. II. Changes during normal pregnancy. Placenta 2004; 25: 114-26. [CrossRef]

34. Muttukrishna S, Suri S, Groome NP, Jauniaux E. Relationships between TGF $\beta$ proteins and oxygen concentrations inside the first trimester human gestational sac. PLoS ONE 2008; 3: e2302. [CrossRef]

35. Plaisier M, Rodrigues S, Willems F, Koolwijk P, van Hinsbergh VW, Helmerhorst FM. Different degrees of vascularization and their relationship to the expression of vascular endothelial growth factor, placental growth factor, angiopoietins, and their receptors in firsttrimester decidual tissues. Fertil Steril 2007; 88: 176-87. [CrossRef]

36. Smith GC, Crossley JA, Aitken DA, Jenkins N, Lyall F, Cameron AD, et al. Circulating angiogenic factors in early pregnancy and the risk of preeclampsia, intrauterine growth restriction, spontaneous preterm birth, and stillbirth. Obstet Gynecol 2007; 109: 1316-24. [CrossRef]

37. Vuorela P, Hatva E, Lymboussaki A, Kaipainen A, Joukov V, Persico MG, et al. Expression of vascular endothelial growth factor and placenta growth factor in human placenta. Biol Reprod 1997; 56: 489-94. [CrossRef]

38. Romero R, Nien JK, Espinoza J, Todem D, Fu W, Chung H, et al. A longitudinal study of angiogenic (placental growth factor) and antiangiogenic (soluble endoglin and soluble VEGF receptor-1) factors in normal pregnancy and patients destined to develop preeclampsia and deliver a small-for-gestational-age neonate. J Matern Fetal Neonatal Med 2008; 21: 9-23. [CrossRef]

39. Muttukrishna S, Swer M, Suri S, Jamil A, Calleja-Agius J, Gangooly S, et al. Soluble Flt-1 and PIGF: New Markers of Early Pregnancy Loss? PLoS ONE 2011; 6: e18041. [CrossRef]

40. Pauli SA, Tang H, Wang J, Bohlen P, Posser R, Hartman T, et al. The Vascular Endothelial Growth Factor (VEGF)/VEGF Receptor 2 Pathway Is Critical for Blood Vessel Survival in Corpora Lutea of Pregnancy in the Rodent. Endocrinology 2005; 146: 1301-11. [CrossRef]

41. Papazoğlu D, Galazios G, Papatheodorou K, Liberis V, Papanas N, Maltezos E, et al. Vascular endothelial growth factor gene polymorphisms and idiopathic recurrent pregnancy loss. Fertil Steril 2005; 83: 959-63. [CrossRef]

42. Douglas NC, Tang H, Gomez R, Pytowski B, Hicklin DJ, Sauer CM, et al. Vascular Endothelial Growth Factor Receptor 2 (VEGFR2) Functions to Promote Uterine Decidual Angiogenesis during Early Pregnancy in the Mouse. Endocrinology 2009; 150: 3845-54. [CrossRef]

43. Shibuya M. Differential Roles of Vascular Endothelial Growth Factor Receptor -1 and Receptor-2 in angiogenesis. J Biochem. Mol. Biol 2006; 39: 469-78. [CrossRef]

44. Chai J, Jones MK, Tarnawski AS. Serum response factor is a critical requirement for VEGF signaling in endothelial cells and VEGFinduced angiogenesis. The FASEB J 2004; 18: 1264-6. 